\title{
A Lei de Licença Prévia e o Mandado de Segurança
}

\author{
ARNOLd WALD
}

\begin{abstract}
A nova lei de licença prévia, procurando coibir os abusos que vinham desfalcando o Tesouro Nacional e perturbando a política anti-inflacionista do govêrno, estabeleceu que os mandados de segurança relativos à entrada de bagagens no território nacional só poderiam ser executados depois do julgamento de tribunal de segunda instância a menos que seja oferecida caução idônea correspondente a $\mathbf{1 5 0 \%}$ do valor das referidas bagagens. A lei obedeceu, ao firmar essas condições, a um imperativo econômico. Tècnicamente, todavia, devemos considerar que está haveñdo, por parte do legislador uma deturpação do instituto. Já quando se impôs o recurso ex-officio, sofreu o mandado de segurança uma limitação na sua função de remédio processual eficaz e rápido para a defesa dos direitos individuais lesados pelos poderes públicos. Os poderes de suspender a execução do mandado de segurança concedido em primeira instância - faculdade dada ao presidente do Tribunal Federal de Recursos - também foram considerados por alguns juizes daquela côrte como inconstitucionais. Agora, nova restrição vem sendo feita. Exige-se, para que o mandado de segurança concedido possa ser executado antes do julgamento do recurso, que haja caução de valor superior à causa. A própria essência do mandado de segurança está sendo transformada. Desaparece paulatinamente da nossa legislação a conquista ligada à tẹoria brasileira do habeas-corpus de Rui Barbosa e Pedro Lessa, que é o mandado de segurança. Os direitos certos e líquidos devem já agora necessàriamente ser reconhecidos pelas duas instâncias, não podendo ser executado o mandado concedido pelo juiz singular sem apresentação de uma caução. A técnica jurídica do mandado de segurança sofreu um pesado golpe. Outros podiam ser os caminhos escolhidos pelo legislador para proteger a economia nacional e evitar as entradas ilegais de mercadorias no país. O precedente aberto, a restrição imposta, a transformação do processo do mandado de segurança é uma diminuição sofrida pelo nosso direito administrativo. Esperamos que não vá mais longe a campanha de combate a um instituto útil e fecundo, profundamente necessário, que alguns abusos não podem definitivamente comprometer.
\end{abstract}

